\title{
Ossifying Fibroma of the Lumbar Spine: Case Report
}

\author{
Lumbar Spinanin Ossifiye Fibromu: Olgu Sunumu
}

\author{
Haydar USUL ${ }^{1}$, Ertugrul CAKIR ${ }^{1}$, Erhan ARSLAN ${ }^{1}$, Safak ERSOZ $^{2}$, Suleyman BAYKAL ${ }^{1}$ \\ ${ }^{1}$ School of Medicine, Karadeniz Technical University, Department of Neurosurgery, Trabzon, Turkey \\ ${ }_{2}^{2}$ School of Medicine, Karadeniz Technical University, Department of Pathology, Trabzon, Turkey
}

Correspondence address: Haydar USUL / E-mail: husul@meds.ktu.edu.tr

\begin{abstract}
Ossifying fibroma of the vertebra is a very rare condition. We report a 16-year-old boy with ossifying fibroma of the third lumbar vertebra. Neurological and laboratory examinations demonstrated normal findings. Low-back pain, in the absence of radicular pain, was the presenting symptom. Plain radiography and computerized tomography scanning revealed an osteolytic lesion. The tumor in the third lumbar vertebra was curetted and filled with bone allograft. The histopathological diagnosis was consistent with ossifying fibroma. There was no postoperative complication. The case is the second to be reported. The clinical and radiological aspects of this rare tumor are discussed with the pertinent literature.
\end{abstract}

KEYWORDS: Ossifying fibroma, Lumbar spine, CT of spine, Fibro-osseous lesion

öz

Vertebranın ossifiye fibromu çok nadir bir durumdur. Üçüncü lumbar vertebrasında ossifiye fibrom olan 16 yaşında bir çocuğu sunmaktayız. Nörolojik ve laboratuvar tetkikleri normal olarak belirlendi. Radiküler ağrı olmaksızın bel ağrısı geliş semptomlarıydı. Düz radyografi ve bilgisayarlı tomografi görüntülemeleri osteolitik bir lezyonu açığa çıkardı. Üçüncü lumbar omurgadaki tümör kürete edilip allograft kemik ile dolduruldu. Histopatolojik değerlendirmesi ossifiye fibrom ile uyumlu geldi. Postoperatif komplikasyon olmadı. Bu vaka yayınlanan ikinci vakadır. Bu nadir tümörün klinik ve radyolojik görüntüleri güncel literatür eşliğinde tartışıldı.

ANAHTAR SÖZCÜKLER: Ossifiye fibrom, Lumbar spina, Spinal CT, Fibro-osseöz lezyon

\section{INTRODUCTION}

Ossifying fibromas are fibro-osseous lesion. The true incidence and common locations vary widely among reports. They most commonly occur in the mandible and maxilla $(4,5)$ and also in the long bones of the lower extremities $(2,5)$. The most common sites in the cranium are the frontal and temporal bones (4). Ossifying fibroma of the vertebra is a very rare condition (5). Here we report the second case of an ossifying fibroma of the lumbar vertebra in a 16 -year-old boy. The clinical significance and management of this rare lesion are discussed with a review of the pertinent literature.

\section{CASE REPORT}

A 16-year-old boy was admitted to our department with low back pain. The patient had low back pain for 18 months and the pain had increased in the last three months. Neurological and laboratory examinations demonstrated normal findings. The plain lumbar radiography revealed an osteolytic lesion involving the left part of the L-3 vertebral body. Lumbar CT scans revealed a soft-tissue density mass of $3.5 \times 2 \times 2 \mathrm{~cm}$. in size at the L3 vertebra body involving the median and posterior part of the corpus and destructing the posterior cortex, and showing minimal extension into the spinal canal with perilesional sclerosis (Figure 1A). Bone window CT scan showed vertebral body destruction (Figure 1B, C). We recommended en bloc resection of the L3-vertebral body but the parents of this young boy rejected any aggressive surgical intervention. The tumor was then resected subtotally and the curettage cavity filled with allograft bone chips.

Histopathological examination revealed a lesion characterized by fibroblastic stroma involving trabecular bone tissue surrounded by osteoblastic cells. Fibroblastic cells formed a storiform pattern in some areas. Hemosiderin-laden macrophages and a few osteoclastic multinuclear giant cells were also present in the lesion. The histopathological diagnosis was consistent with ossifying fibroma (Figure 2).

The postoperative period was uneventful, and the patient was discharged on the seventh postoperative day. The followup lumbar CT scan taken 18 months later showed the residual tumor and microcalcification located at the posterior portion of the L3 vertebra corpus. No dural sac compression was observed (Figure 3). 


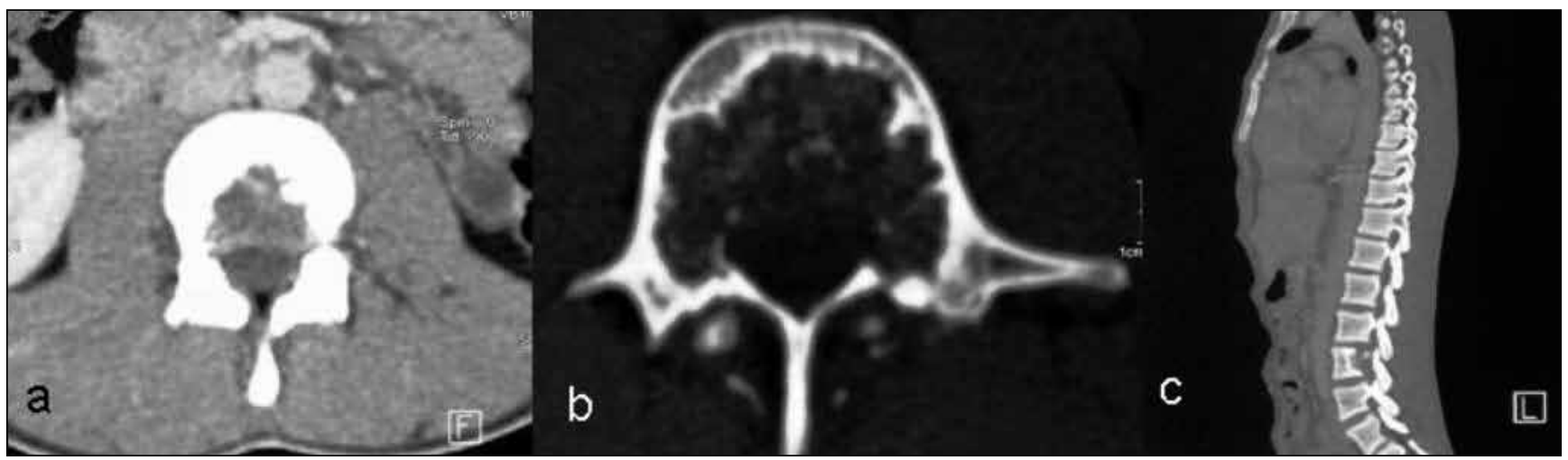

Figure 1: A) Lumbar CT scans show a soft-tissue density mass at the median and posterior part of L3 vertebra corpus that was destructing the posterior cortex, showing minimal extension into the spinal canal with perilesional sclerosis. Axial B) and sagittal C) bone window CT scans show vertebral body destruction.

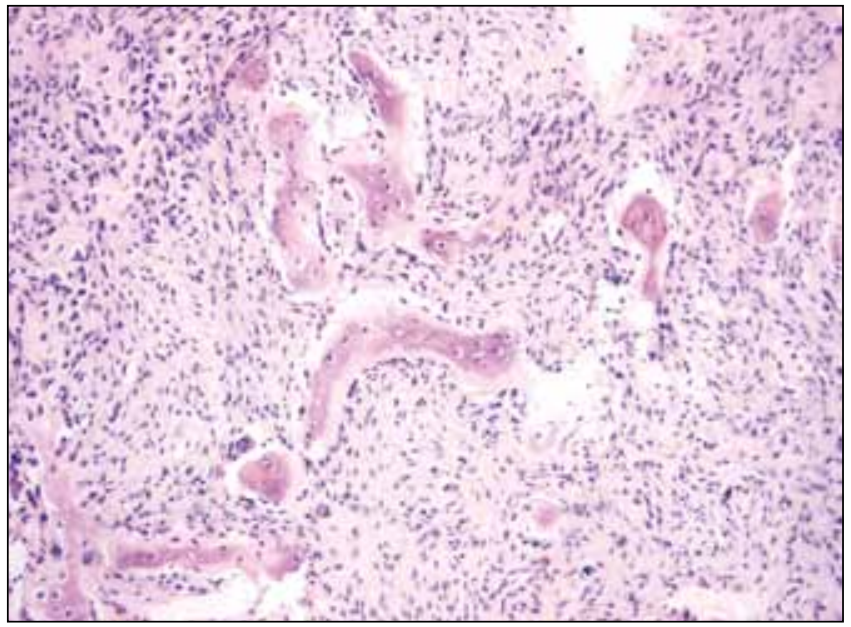

Figure 2: Histopathological examination shows irregular trabeculae rimmed by osteoblasts in fibroblastic stroma (HE $\mathrm{x}$ 200).

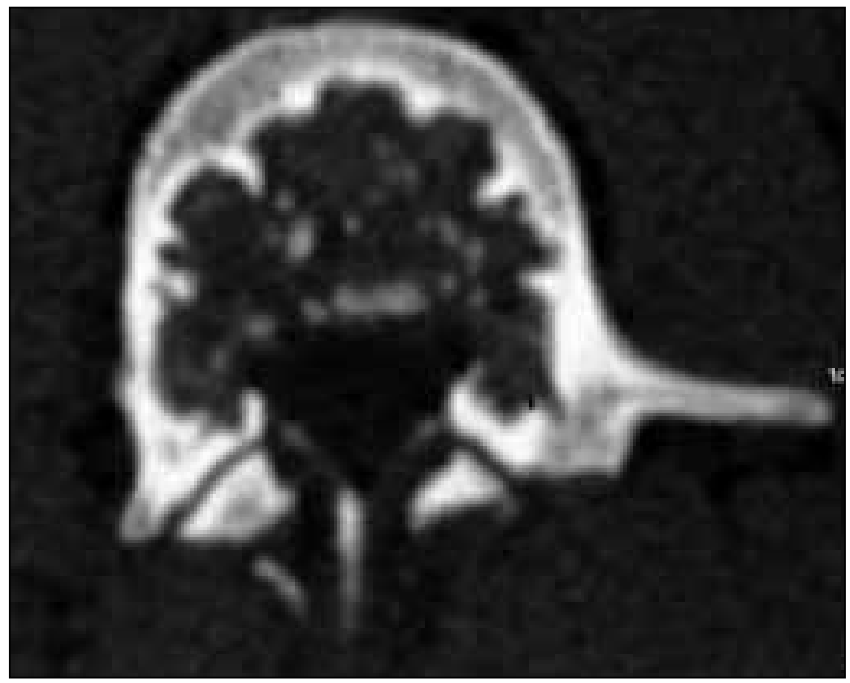

Figure 3: The follow-up lumbar CT scan shows the residual tumor and microcalcification located at the posterior portion of the L3 vertebra corpus. No dural sac compression was observed.

\section{DISCUSSION}

Primary spinal neoplasms account for less than $10 \%$ of all tumors seen in the spinal column (1). The mean age at diagnosis is approximately 21 years for benign lesions of the spine, and approximately 49 years for malignant lesions (6).

Ossifying fibroma is a very rare lesion, and is more common in females. It appears in patients before the age of 40 , with a peak incidence in the third and fourth decades (4). Ossifying fibroma most commonly occurs in the mandible and maxilla $(4,5)$. The frontal and temporal bones are the most common sites in the calvarium (4). It also grows in the long bones of the lower extremities $(2,5)$. These lesions present as a slowlygrowing mass that is initially asymptomatic. Symptoms and signs depends on the location of the tumor.

Radiographically, ossifying fibromas are initially radiolucent lesions. They gradually become radiopaque with calcifications. Expansion of involved bone with the preservation of a thin rim of cortex is seen in ossifying fibromas. Dilated vascular channels are seen in skull films. CT scans reveal a welldelineated dense lesion. Scalp and dural feeding vessels are occasionally revealed by angiography. Radionuclide 99m Tc scans also may be positive (4).

Computerized tomography plays a major role in the differential diagnosis of ossifying fibroma from aneurysmal bone cyst, giant cell tumor, osteoid osteoma and osteoblastoma (3).

Osteoid osteoma is a small benign, primary bone tumor composed of atypical bone and an osteolytic nidus surrounded by a thick sclerotic reaction. CT findings of a smooth, round lucent nidus less than $15 \mathrm{~mm}$ in diameter, surrounded by a well-defined sclerotic area are pathognomonic. Osteoblastoma generally attacks the neural arch and affects the spinal column in $25-50 \%$ of cases. The vertebral corpus is rarely involved. The nidus of the osteoblastoma is often poorly circumscribed and is larger than that of the osteoid osteoma. Surrounding sclerosis is not prominent but may be seen. Paraspinal extension and extension into spinal canal may occur. Aneurysmal bone cyst is an uncommon, benign, 
markedly expansile bone lesion that affects a single vertebra. CT shows characteristically marked "aneurysmal" cortical "eggshell" expansion and thinning, enclosing a noncalcified cyst. Giant cell tumors are rare, destructive lytic bone tumors that may involve the vertebral body, pedicle, or neural arch, and pathological fractures may cause pain. CT demonstrates a lytic noncalcified expansile mass that may have a benign appearance, similar to an aneurysmal bone cyst, but the lesion may also expand into surrounding soft tissues in a more aggressive fashion.

Ossifying fibroma is a slow-growing sharply marginated benign tumor. It is composed of a fibrous stroma with varying amounts of woven bone, but has areas of mature lamellar bone at the periphery. It is a part of the spectrum of fibroosseous lesions that includes fibrous dysplasia. The only feature that separates ossifying fibroma from fibrous dysplasia is the presence of a "capsule" of lamellar bone, surrounding an ossifiying fibroma (4).

Histopathological examination shows a cellular fibrous spindle cell growth in whorled or matted pattern. Bony fragments can be observed as in meningioma psammoma bodies. Woven bone spicules circumscribed by lamellar bone development are present. Woven bone appears first matures into lamellar bone. Polarization of widely-spaced parallel birefringent lines and osteoblastic and osteoclastic rim of trabeculae in the lamellar bone are some distinguishing characteristics of lamellar bone. Fibrous dysplasia may be recognized by random birefringence under polarized light. $A$ giant cell reaction, hemorrhage and inflammation may also be observed in fibrous dysplasia (4).

The differential diagnosis of fibro-osseous lesions must include not only ossifying fibroma and fibrous dysplasia but also reactive bone formation. Spicules of bone appear along the lines of trauma with woven bone undergoing complete maturation to lamellar bone in reactive bone formation, and additional endochondral bone formation is also present.

Juvenile ossifying fibroma is a rapidly growing destructive lesion of the maxilla occurring before the age of 15. Extension into the paranasal sinuses and orbit is common. This lesion is histologically identical to the adult tumor, but its aggressive local invasion can be fatal.

Our patient is the second case in the literature with ossifying fibroma of the spine. The first one was reported by Ohyama et al. in 1992 (5). The follow up of our patient is eighteen months, and this is a short follow-up period for these patients.

Total surgical excision is the preferred treatment of ossifying fibroma. Subtotal removal should be considered in extremely large lesions and the lesions of the skull base with excellent outcomes of more than ten years. Radiation therapy for the treatment of these tumors has also been reported but malignant transformation limits this application (4).

\section{REFERENCES}

1. Abdu WA, Provencher $M$ : Primary bone and metastatic tumors of the cervical spine. Spine 23(24):2767-7277, 1998

2. Georgen TG, Dickman PS, Resnick D, Saltzstein SL, O'Dell CW, Akeson WH: Long bone ossifying fibroma. Cancer 39:2067-2072, 1977

3. Grossman CB: Other spinal pathological conditions . In: Magnetic resonance imaging and computed tomography of the head and spine, 2nd edn. Baltimore: Williams \& Wilkins, 1996:751-794

4. Hamilton HB:Tumors of the skull. In: Neurosurgery, 2nd edn. New York: McGraw-Hill, 1996:1503-1528

5. Ohyama T, Ohara S, Momma F, Moto A, Nakata Y: Ossifying fibroma of the thoracolumbar spine: A case report and review of the literature. Surg Neurol 37(3):231-235, 1992

6. Weinstein JN, McLain RF: Primary tumors of the spine. Spine 12(9):843-851, 1987 